\title{
PHYSICAL CONDITIONING OF TEENAGERS IN DIFFERENT KIND OF SPORTS
}

\author{
Ugis Ciematnieks \\ Rīga Stradiņš University, Latvia \\ Beāte Streike \\ Rīga Stradin̄š University, Latvia
}

\begin{abstract}
Physical conditioning is crucial in building motion skills if the coach wants to ensure long-term athletic development. The essence is that physical conditioning needs to be developed before the development of technical skills of sports movements at a much higher intensity at each stage of the multi-annual training process. The adult competition system and training programs are being imposed on young athletes, so the essential motion skills are not being learned (Grävittis \& Luika, 2015). The lack of physical conditioning in teenage years is very often reflected in the most inappropriate moments of an athlete's career, at the elite level. Insufficient physical conditioning is a reason for the instability of motion skills and injuries in extreme physical and psychological loads. The amount of physical activity can be measured as a step count. The aim of the research is to assess physical fitness rate for children practicing basketball, football or ice hockey with EUROFIT test battery. The study included boys, 100 basketball players, 100 soccer players and 100 ice hockey players from Latvia who were born in 2002 and started training in their sport during at the ages from 7 to 9, collected data of their conditioning for five years, divided into three age groups. According to EUROFIT tests, it was concluded that the ice hockey players have the highest physical conditioning rates according to EUROFIT standard from the athletes analyzed, and the basketball players have the lowest physical conditioning rates in EUROFIT tests from the athletes analyzed. We can conclude that the results of hockey players are higher than the scores of basketball and soccer players because ice hockey players practice more frequently, and dryland training is strictly organized, they develop all motor abilities that is needed for successive training in basic drills on ice.
\end{abstract}

Keywords: Eurofit tests, physical conditioning, schoolchildren.

\section{Introduction}

The adult competition system and training programs are imposed on young athletes, so that the essential movement skills are not learned (Grāvītis \& Luika, 2015).

A similar opinion is voiced by sports doctor Sandra Rozenštoka, writing about the young basketball players playing in U18 or U20 teams, saying those players have low physical fitness. The doctor believes that these basketball players have not had enough time to develop physical conditioning in their daily 
lives, because they have a disproportionately large number of games to play. The number of games is also the reason why athletes are not able to recover from games and thus the consequences of overloading the body. The doctor is also considering the early competitions from the age of eight, which for many suppress the pleasure of playing (Rozenštoka, 2016).

The lack of physical conditioning in the teenage and young adult's age is very often reflected in the most inappropriate moments of an athlete's career, at the elite level. Insufficient physical conditioning is a reason for the instability of motion skills and injuries in extreme physical and psychological loads. For athletes in late puberty and young age, if there is insufficient physical fitness, it negatively impacts future growth as a professional athlete. General conditioning is the basis for optimal development of the athlete in sport (Grāvītis \& Luika, 2015).

The aim of the study: to assess physical conditioning rates for children practicing basketball, football and hockey.

Study methods: as methods we used a data collection of EUROFIT test results and descriptive statistics with SPSS Statistics.

\section{Literature review}

Physical conditioning is the development and maintenance of a person's physical abilities - speed, endurance, strength, agility and flexibility.

Nowadays, sports scientists are increasingly emphasizing the specifics of sport in physical training. This means in practice that there is a significant dominance of special physical training over general conditioning. However, the basis of any special training is general or physical conditioning. During the first two years, the child should develop general physical conditioning and learn a variety of movement and exercise skills. Specialization in a sport can be started from the third year of sport activities (Rozenštoka, 2016).

There are three basic principles to be followed in training of youth athletes: regularity, graduality and suitability. This means that a physical conditioning exercises should be included in each workout. It is about building strength for all the major muscle groups in the body. The leg muscles are most suitable for speed (explosive strength) or jumping exercises, which are useful for all sports. These are all sorts of jumps on the subject, across the subject, sideways jumps, leg to leg jumps, and so on. Considering the principle of graduality, initially, the duration, speed, and workload of these and other strength exercises should not be high according with the level of preparedness, to avoid significant fatigue and used as a transition from one exercise mode to another. Following the third basic principle of suitability, one should spend with a little more training time initially. Each athlete should be individually assessed for the workload and intensity of training. 
At least five core muscle group exercises must be applied per workout for athletes of all ages, not only in conditioning but also in competition period, which will ensure their long-term sports career (Kravalis, 2008).

Training in a variety of sports enhances physical condition according to the specifics of the sport. Basketball is defined as a sport that requires one to be physically strong - requiring players to frequently repeat intense movements such as sprints, jumping, including short recovery breaks. Sports include both aerobic and anaerobic energy processes. A basketball player must be well-prepared to be a high level athlete - with optimally developed explosive strength, agility, coordination, good anaerobic ability and good aerobic endurance (Pojskić, Haris, Šeparović, Vlatko, \& Muratović, 2014).

For a basketball player, it is important to develop all types of strength maximum strength - the greatest strength a player can develop in dynamic or static form to overcome resistance, a explosive speed - ability to give movement to body or body parts as quickly as possible, strength endurance - to resist muscle fatigue for sustained loads that require both strength and endurance (Pojskić, Haris, Šeparović, Vlatko, \& Muratović, 2014).

Factors determining the physical characteristics of a football player include agility and coordination - accuracy of movement, versatility of technical - tactical actions; neuromuscular properties - speed and agility during a movement; metabolic properties - aerobic and anaerobic endurance; muscle properties muscle strength and explosive strength; plastic properties - flexibility, muscle elasticity and mobility. A football player needs both good aerobic and good anaerobic endurance. Aeorbic endurance is expressed in moderate intensity loads at the expense of a biological oxidation reaction. Anaerobic endurance is manifested at peak and submaximal loads at the expense of a biological ATP synthesis reaction that does not involve oxygen. Due to the fact that the maximum speed running distance in football is 10-40 meters, the main source of energy is the anaerobic alactic path - phosphogene ATP synthesis.

The main motor abilities that ice hockey players must develop are strength, speed, endurance and coordination. Strength is an important component in ice skating because the strength of the core muscles keeps the athlete's body in the correct position, while strong leg muscles promote strong thrust during skating. Speed is a key factor in hockey, which determines the overall level of play. Very often during a game, a hockey player must be able to make quick movements, react quickly, or change directions rapidly. Therefore, it is also important to develop speed. Also, endurance is a very important part of a hockey player's physical conditioning so that the hockey player can maintain a steady pace of skating and perform various technical and tactical tasks throughout the game. Without well-developed coordination, it is impossible to play high-level hockey. 
Coordination needed to coordinate hands and feet, perform various skating tasks, skating direction changes (Latvijas hokeja federācija, 2013).

Almost all the physical characteristics of the sports games can be tested with the EUROFIT tests, in order to avoid the specifics of the sport and to assess the physical fitness of the young people (Priedīte, Sauka, Kalniņa, \& Lāriņš, 2015). Physical conditioning is the foundation of good health and athletic achievements. The EUROFIT test system assesses physical conditioning, which may not coincide with the level of sport specific conditioning (Priedīte, Sauka, Kalnina, \& Lāriņš, 2015).

The analysis of standardized, uniform EUROFIT test results will provide an opportunity to regularly obtain up-to-date data on the physical conditioning, work capacity and development trends of children, adolescents and adults, as well as to compare data with other European countries (Tomkinson, Carver \& Atkinson, 2017).

\section{Methodology}

The data collection took place from 1st September to 1st November of 2019. Our study involved 300 male athletes from Latvia - 100 basketball players, 100 soccer players, 100 ice hockey players born in 2002, started training in their sport at the age of 7-9 and performed EUROFIT test tests three times in the age from 12 to 17, tests included - absolute hand grip, relative hand grip, flamingo balance, plate tapping, sit-and-reach, standing broad jump, sit-ups in 30 seconds, bent arm hang and PWC170. Also we used overall level in all tests, extended to score in balls, where 1 - "low level" and 5 - "high level". Data were collected from children's medical books at the Sports Medical Centre.

The research methodology was approved by the Ethics Committee of Riga Stradiņš University on 04.07.2019, as well as the permission for data analysis was obtained from Sports Medicine Center.

Data is published anonymously at work, considering to the principle of confidentiality.

\section{Research results}

Anthropometric results show that basketball players in age group of 12-13 years are tallest and heaviest, and therefore have the highest BMI. In the age group of 14-15, basketball players are also the tallest, heaviest and with the highest BMI. In the age group of 16-17, ice hockey players have similar results to basketball players. 
SOCIETY. INTEGRATION. EDUCATION

Proceedings of the International Scientific Conference. Volume VI, May $22^{\text {th }}-23^{\text {th }}, 2020.142-149$

Table 1 Anthropometrics of sportsmen in different sports and age groups

\begin{tabular}{|l|c|c|c|c|}
\hline & $\begin{array}{c}\text { Age } \\
\text { group }\end{array}$ & Height, cm & Weight, kg & BMI \\
\hline \multirow{4}{*}{ Basketball } & $\mathbf{1 2}-\mathbf{1 3}$ & $165.4 \pm 11.22$ & $52.13 \pm 9.46$ & $20.62 \pm 2.68$ \\
\cline { 2 - 5 } & $\mathbf{1 4}-\mathbf{1 5}$ & $173.26 \pm 10.02$ & $60.51 \pm 11.49$ & $20.3 \pm 2.31$ \\
\cline { 2 - 5 } & $\mathbf{1 6}-\mathbf{1 7}$ & $180 \pm 9.22$ & $68.9 \pm 11.39$ & $21 \pm 2.31$ \\
\hline \multirow{4}{*}{ Football } & $\mathbf{1 2}-\mathbf{1 3}$ & $157.3 \pm 10.21$ & $46.5 \pm 9.57$ & $18.12 \pm 0.21$ \\
\cline { 2 - 5 } & $\mathbf{1 4}-\mathbf{1 5}$ & $166.67 \pm 11.02$ & $56.16 \pm 10.52$ & $19.1 \pm 2.20$ \\
\cline { 2 - 5 } Ice hockey & $\mathbf{1 6}-\mathbf{1 7}$ & $175.4 \pm 8.42$ & $65 \pm 8.98$ & $20 \pm 2.20$ \\
\hline & $\mathbf{1 2}-\mathbf{1 3}$ & $158.6 \pm 8.87$ & $49.83 \pm 9.94$ & $19.46 \pm 2.51$ \\
\cline { 2 - 5 } & $\mathbf{1 4}-\mathbf{1 5}$ & $165.6 \pm 9.50$ & $56.7 \pm 10.83$ & $20 \pm 2.39$ \\
\cline { 2 - 5 } & $\mathbf{1 6}-\mathbf{1 7}$ & $173.06 \pm 7.47$ & $64.8 \pm 9.67$ & $20.9 \pm 2.21$ \\
\hline
\end{tabular}

$n=300$ (in each age group)

All results in levels where shown in radar charts to see overall physical conditioning level in selected sports.

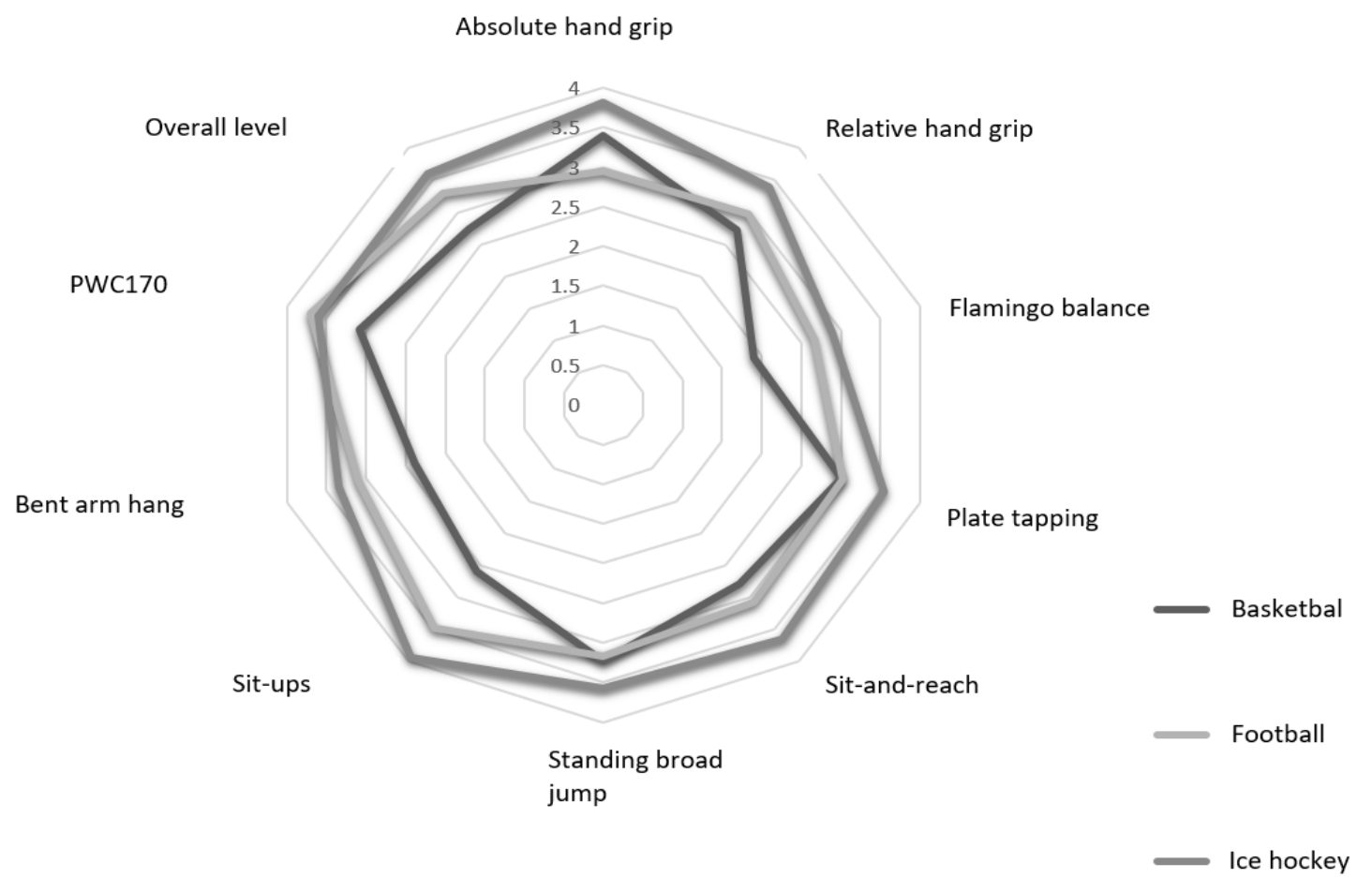

Figure 1 EUROFIT results in age group 12-13 years, $n=300$

In Figure 1 radar diagram we can see that ice hockey players shows the broadest and smoother trend of results that their physical conditioning is better than other kind of sports. We payed attention to low balance test results are low for all subjects - basketball players had in average 1.9 level points, football 
players 2.6 and ice hockey players 2.9 level points - good balance is essential in sport games, especially ice hockey, but children lack it. We can explain this with beginning of puberty, changing body composition in this age that leads to decreasing balance. Although basketball players also had lower results in sit-ups test -2.59 level points and bent arm hang -2.30 level points. We can describe this with insufficient general conditioning in basketball training process.

As we can see in Figure 2, ice hockey players dominates in this age group also, but profile of basketball players gets wider and they got more of conditioning in every side. In this age group we also observe low results for all players in balance test (basketball 2.13, football 2.6 and ice hockey 2.9 level points), and for ice hockey test results even decrease in this age group. We can explain this with continuous puberty, which can affect balance and agility as well.

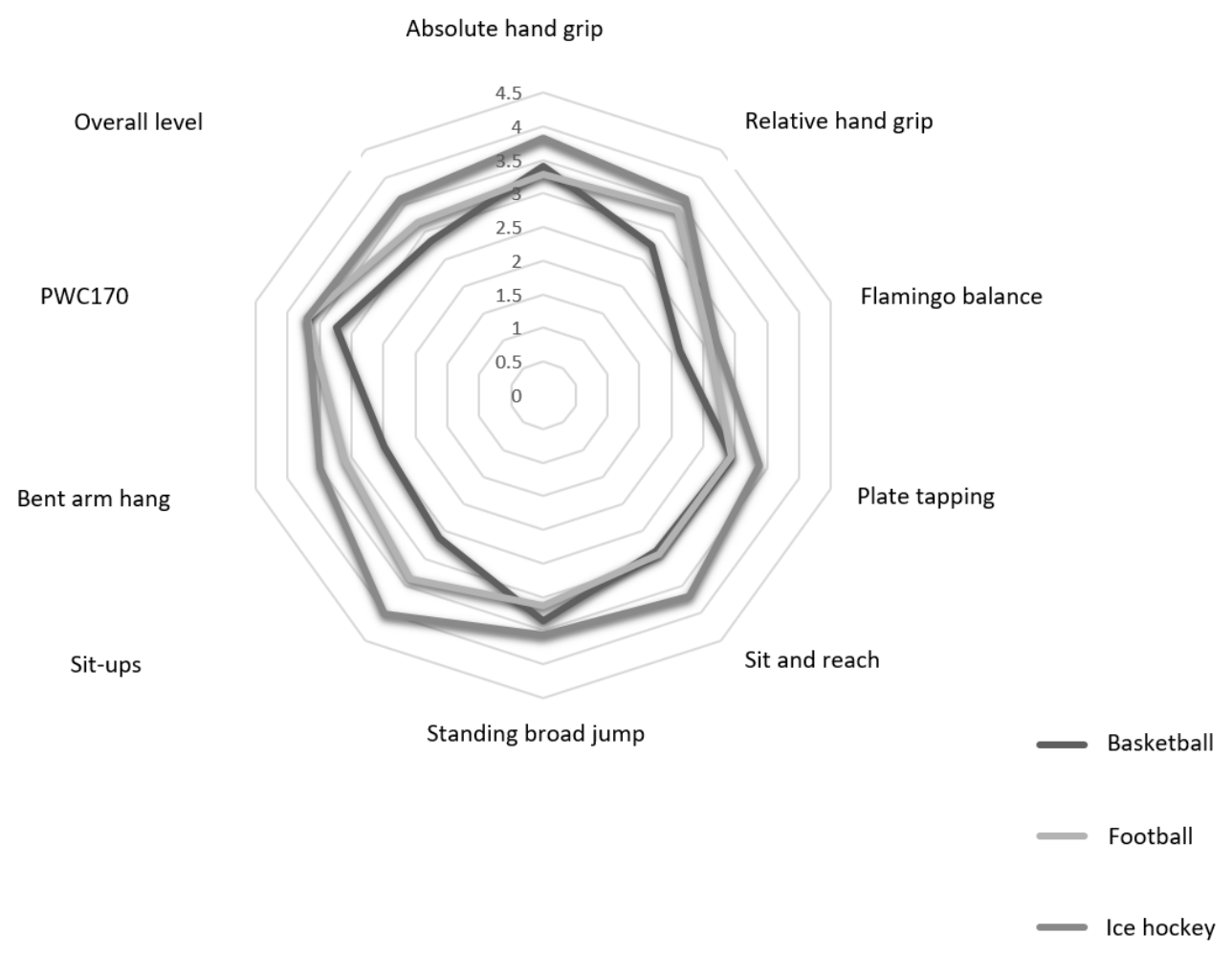

Figure 2 EUROFIT results in age group 14-15 years, $n=300$

In Figure 3 we can observe, that football players start to dominate in relative hand grip strength. This factor cannot be explained because football specifics does not require hand grip strength, but in ice hockey players must hold a hockey stick. 


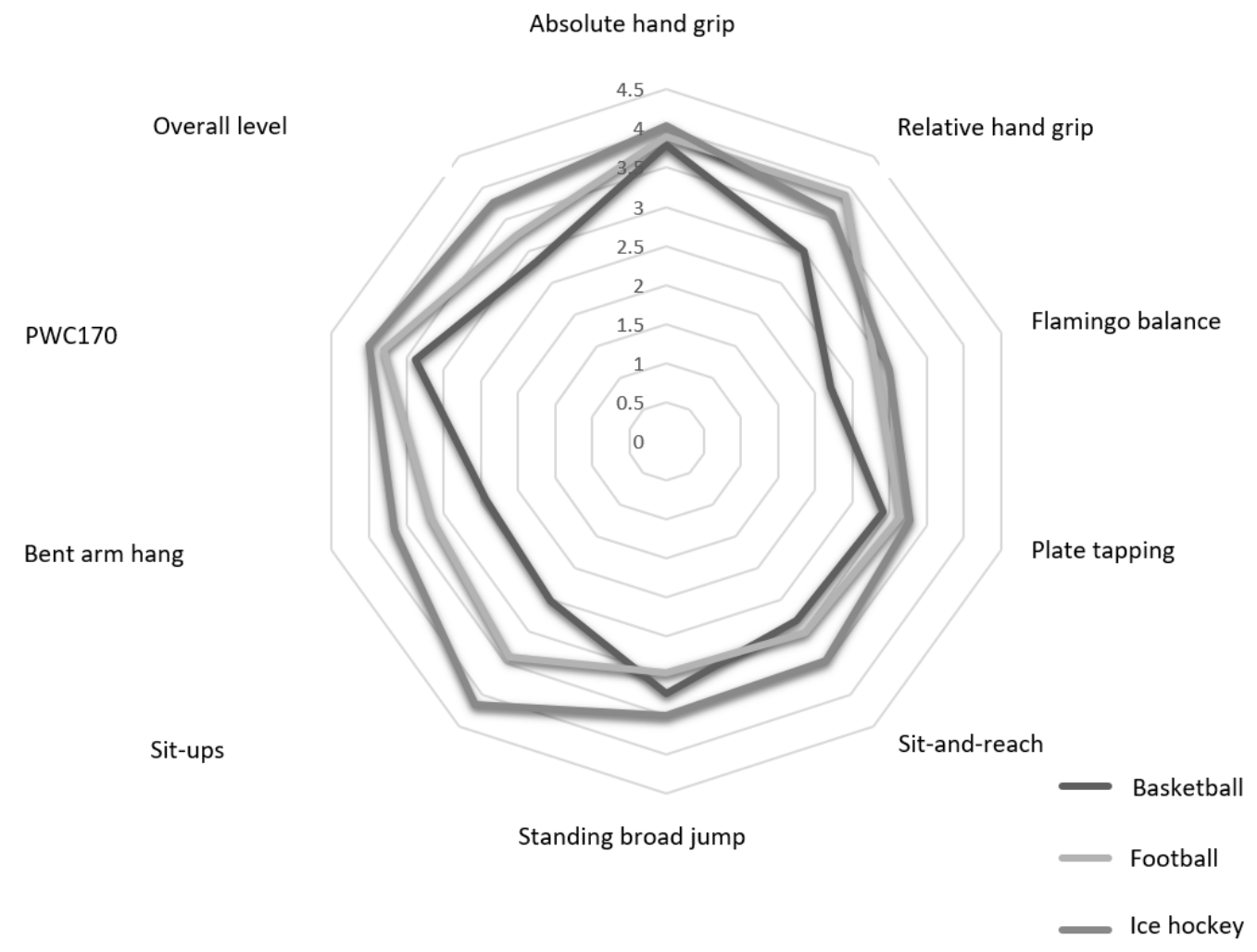

Figure 3 EUROFIT results in age group 16-17 years, $n=300$

Balance in this age group must be in high level as sportsmen must be ready to participate with adult teams in national championships, in this competition level all physical qualities must be in high level, as static or dynamic balance condition affect gameplay directly.

\section{Conclusions}

Ice hockey players have the highest physical conditioning scores of the analyzed athletes, expressed in EUROFIT test level (3.6 in the 12 - 13 age group, 3.6 in the 14-15 age group, 3.78 for 16-17 age group), basketball players have the lowest physical fitness scores in EUROFIT tests from the athletes analyzed (2.75 in the 12-13 age group, 2.84 in the 14-15 age group, 2.83 in the 16-17 age group).

The highest scores for all observed athletes are in the "absolute hand grip" test (average for basketball players - 3.56, footballer - 3.37, ice hockey player 3.9), lowest results in Flamingo balance (average for basketball players - 2.06, footballers 2.68, ice hockey players - 2.86). We can explain ice hockey players have higher results than basketball players and footballers: ice hockey players have dryland trainings for developing motor abilities as well as trainings-on-ice for specific hockey drills and special conditioning, so ice hockey players may 
have five to six trainings per week (Latvijas Hokeja federācija, 2019). As a result of the study, we can make the following suggestions:

- According to athletes having a low result in the flamingo balance test, basketball, football and ice hockey sports schools should include extra balance exercises in their training plans;

- It is important to focus on developing abdominal muscles for basketball players and football players, considering the average abdominal muscle test results (sit-ups test);

- $\quad$ Basketball and football sports schools should provide regular five-week training sessions, including both technical training directly on the field and physical conditioning development.

Schoolchildren lack of general physical conditioning (Rozenstoka, 2016), even with attending sports classes at school and sports specific training. This research show, that with two required sport classes a week and additional three times of sports specific training in football and basketball is not enough to show good or high results in EUROFIT test battery, so it seems that they lack everyday physical activities, that cannot be compensated with sport specific training. Moreover, if they cannot show acceptable results in balance test, then possibility of injury significantly raises and can be a reason of youth to decrease physical activities and quit a sport classes.

\section{References}

Grāvītis, U., \& Luika, S. (2015). Vispusīgās fiziskās sagatavotības trenera rokasgrāmata. Rīga, SIA “DUE”.

Kravalis, I. (2009). Doctoral thesis "Studentu vispusīgās fiziskās sagatavošanas pilnveide dienestam policijā" Rīga, Latvijas Sporta pedagog̣ijas akadēmija.

Latvijas Hokeja federācija. (2019). Profesionālās ievirzes sporta izglìtības programma hokejā. Retrieved from https://hf.lv/lv/hokeja_progamma

Pojskić, H., Šeparović, V., Muratović, M., \& Užičanin, E. (2014). The relationship between physical fitness and shooting accuracy of professional basketball players. Motriz: Revista de Educação Física, 20(4), 408-417.

Priedīte, I.S., Sauka, M., Kalniņa, L., \& Lāriņš, V. (2015). Vispārizglītojošo skolu skolēnu fiziskās sagatavotības izvērtēšana. Rīga, Latvijas Sporta medicīnas asociācija.

Rozenštoka, S. (2016). Sports bērniem. Retrieved from http://www.sportlab.lv/?page_id=781

Tomkinson, G.R., Carver, K.D., \& Atkinson, F. (2017). European normative values for physical fitness in children and adolescents aged 9-17 years: results from eurofit performances representing 30 countries. British Journal of Sports Medicine, 52, 1445-1456. 